\title{
KUALITAS RUMPUT LAUT MERAH (Kappaphycus alvarezii) DENGAN METODE PENGERINGAN SINAR MATAHARI DAN CABINET DRYER, SERTA RENDEMEN SEMI-REFINED CARRAGEENAN (SRC)
}

\author{
Thobias Tamaheang $^{1}$, Daisy M. Makapedua ${ }^{2}$ dan Siegfried Berhimpon ${ }^{2}$ \\ 1) Mahasiswa pada Program Studi Teknologi Hasil Perikanan FPIK Unsrat Manado \\ ${ }^{2)}$ Staf pengajar pada Program Studi Teknologi Hasil Perikanan FPIK Unsrat Manado \\ Email: tobiastamaheang@yahoo.com
}

\begin{abstract}
Red seaweed (Kappaphycus alvarezii) is one type of algae that produced carrageenan Carrageenan can be used as a stabilizer, thickening agent, gelling agent, emulsifier, coagulant agents, colloid protective agents, and crystallization-preventing agents. This property is widely used in the food industry, pharmaceuticals, cosmetics, textiles, paint, toothpaste and other industries. This research aims to determine the yield of semi-refined carrageenan (SRC) and to compare the quality of red seaweed (Kappaphycus alvarezii) prepared by two difference methods i.e. sun drying and artificial drying with various drying time $(12 \mathrm{~h}, 24 \mathrm{~h}$, or $40 \mathrm{~h})$. The results showed that the yield of semi-refined carrageenan (SRC) dried with artificial dryer (56\%) was not within the required of Indonesian national standard for carrageenan. Also, results indicated that the lowest fat content $0.2 \%$ was achieved after $12 \mathrm{~h}$ drying period with cabinet dryer whilst the lowest moisture content was prepared by drying seaweed for $40 \mathrm{~h}$ under the sun.
\end{abstract}

Keyword: $\quad$ red seaweed, semi-refined carrageenan, cabinet dryer.

Rumput laut merah (Kappaphycus alvarezii) merupakan salah satu jenis rumput laut penghasil karaginan, Karaginan sangat penting peranannya sebagai stabilisator (pengatur keseimbangan), thickener (bahan pengental), pembentuk gel, pengemulsi, koloid pelindung, penggumpal dan pencegah kris talisasi. Sifat ini sangat dimanfaatkan dalam industri makanan, obat-obatan, kosmetik, tekstil, cat, pasta gigi dan industri lainnya. Penelitian ini bertujuan untuk mempelajari serta mengetahui perbedaan kualitas dari rumput laut merah yang dikeringkan dengan menggunakan dua metode yaitu pengeringan dengan sinar matahari dan pengeringan dengan alat pengering buatan (cabinet dryer), serta rendemen semi refinedcarrageenan (SRC). Hasil yang diperoleh dari penelitian ini menunjukkan bahwa kualitas karaginan yang terbaik yang dikeringkan pada perlakuan B1 (cabinet dryer) selama 12 jam dimana kadar lemak yaitu $0,2 \%$, serat kasar tertinggi yaitu $6.5 \%$ pada perlakuan A1 (sinar matahari) selama 24 jam (08.0012.00), karbohidrat tertinggi yaitu $14,72 \%$, pada perlakuan A1(sinar matahari) selama 24 jam (08.0012.00), kadar air terendah pada perlakuan A1 (sinar matahari) selama 40 jam (12.00-16.00) yaitu $10,75 \%$, kadar lemak terendah terdapat pada perlakuan B1 (cabinet dryer) selama 24 jam yaitu 0,22\%. Rendemen SRC yang dikeringkan dengan alat pengering buatan cabinet dryer yaitu $56 \%$.

Kata Kunci: Rumput laut merah, semi-refined carrageenan, cabinet dryer.

\section{PENDAHULUAN}

Rumput laut merupakan salah satu komoditas hasil perikanan yang digolongkan pada golongan tumbuhan atau secara ilmiah disebut dengan algae. Rumput laut di Indonesia dikembangkan sebagai tanaman budidaya, hal ini terlihat pada produksi budidaya rumput laut tahun 2009 sebesar 2,574 juta ton dan tahun 2010 meningkat menjadi 3,082 juta ton. Jenisjenis rumput laut yang telah berhasil dibudidayakan di Indonesia adalah jenis dari genus Eucheuma dan Gracilaria (KKP, 2011).
Kappaphycus alvarezii merupakan salah satu jenis rumput laut penghasil karaginan, jenis karaginan yang dihasilkan yaitu kappa karaginan. Rumput laut diketahui sebagai sumber serat pangan sebesar $78,94 \%$ dan vitamin A (beta karoten), B1, B2, B6, B12, C dan niacin, serta mineral yang penting, seperti kalsium dan zat besi (Astawan $d k k, 2004)$.

Tujuan atau manfaat rumput laut merah dalam penelitian ini adalah untuk melihat kualitas rumput laut kering dari rumput laut jenis Kappahycus alvarezii dengan dua metode pengeringan sinar matahari dan cabinet dryer 
serta rendemen Semi-refined carrageenan (SRC).

\section{METODOLOGI PENELITIAN}

\section{Tempat dan Waktu Penelitian}

Penelitian ini dilaksanakan di

Laboratorium Teknologi Penanganan dan Pengolahan Hasil Perikanan, Laboratorium Pengendalian Mutu Hasil Perikanan, Fakultas Perikanan dan Ilmu Kelautan Universitas Sam Ratulangi Manado. Pelaksanaan kegiatan penelitian ini sampai pada ujian hasil akhir dilaksanakan selama 4 bulan, dimulai dari bulan 01 Juli-16 Desember 2016.

\section{Alat dan Bahan}

Bahan yang digunakan dalam penelitian ini adalah rumput laut merah Kappaphycus alvarezii, air, akuades, ethanol, $\mathrm{NaOH}$, heksana, asam klorida, indikator fenolftalein (PP), larutan, kanji $1 \%$, asam asetat, potassium iodide (KI), sodium tiosulfate $\mathrm{Na}_{2} \mathrm{~S}_{2} \mathrm{O}_{3}$, natrium tiosulfat $\left(\mathrm{Na}_{2} \mathrm{~S}_{2} \mathrm{O}_{3}\right)$.

Alat-alat yang digunakan dalam penelitian ini adalah timbangan analitik, corong saring, stop watch, pompa vakum, saringan, pipet, pengaduk, kain kasa, kertas $\mathrm{pH}$, kertas saring, thermometer, oven, kemasan plastik, labu ukur $100 \mathrm{ml}$, gelas ukur, gelas piala, pemanas listrik, kapas bebas lemak, alat soxhlet, pendingin tegak, pipet gondok $10 \mathrm{ml}$, pipet gondok $25 \mathrm{ml}$, wadah pengering dan alat pengering buatan (cabinet dryer).

\section{Perlakuan dan Rancangan Percobaan}

Perlakuan pada penelitian ini terdiri dari 2 (dua) metode pengeringan dan lama pengeringan yang berbeda:

A. Pengeringan dengan menggunakan tenaga surya (sinar matahari) pada temperatur berkisar $32-38^{\circ} \mathrm{C}$ selama:

A1. 24 jam (jam 08.00-12.00)

A2. 40 jam (jam 12.00-16.00).

B. Pengeringan dengan menggunakan cabinet dryer dengan sumber panas dari kompor dengan suhu berkisar $60^{\circ} \mathrm{C}$ selama:

B1. 12 jam

B2. 24 jam.

\section{Prosedur Penelitian}

\section{Proses Pengeringan Rumput Laut Merah}

Bahan baku yang digunakan adalah rumput laut merah yang diperoleh dari desa Arakan, Kabupaten Minahasa Selatan. Rumput laut yang digunakan dalam penelitian ini yaitu rumput laut basah atau mentah sebanyak $10 \mathrm{~kg}$ dengan umur panen sekitar 2 bulan. Kemudian rumput laut ditaruh dalam cool box dan dibawa ke Laboratorium Teknologi Penanganan dan Pengolahan Hasil Perikanan, Fakultas Perikanan dan Ilmu Kelautan Universitas Sam Ratulangi Manado. Persiapan selanjutnya dalam penelitian ini yaitu pembuatan wadah pengering yang digunakan di bawah sinar matahari, yaitu wadah yang terbuat dari kayu dan berbentuk persegi empat yang dibentuk seperti tirisan dan cabinet dryer menggunakan bahan alumunium sebagai bahan dasar, dapat memanfaatkan sumber energi dari tenaga surya dan dapat menggunakan sumber panas lainnya seperti kompor. Alat pengering ini bisa digunakan untuk jangka waktu yang lama, sehingga mudah dibersihkan dan mudah dalam penyimpanan. Dengan bobot alat yang ringan, dimensi panjang dan lebar hanya $80 \times 80 \times 188,2 \mathrm{~cm}$ (Bintang, $d k k, 2013$ ).

\section{Proses Produksi Semi-Refined Carrageenan (SRC)}

Semi-refined carrageenan (SRC) chips pada intinya dilakukan melalui proses perlakuan alkali dalam kondisi panas yang disebut dengan proses alkali atau proses alkali modifikasi. Adapun tahapannya sebagai berikut:

1. Proses perlakuan alkali: Proses perendaman rumput laut dalam air tawar selama \pm 1 jam.

2. Perebusan selama \pm 10 menit dengan temperatur $80-90^{\circ} \mathrm{C}$ sambil diaduk setelah panas tambahkan larutan $\mathrm{NaOH}$.

3. Netralisasi (pembersihan): cuci rumput laut yang telah melalui perlakuan alkali dengan air tawar hingga netral.

4. Pemotongan (chopping): potong rumput laut yang sudah dibersihkan (netral) dengan ukuran $2-4 \mathrm{~cm}$ dan disimpan dalam wadah pengering.

5. Pengeringan (drying): keringkan potongan kecil rumput laut tersebut dengan cara dikeringkan dalam oven selama 12 jam.

6. Pengemasan: kemas rumput laut bentuk chips tersebut dalam kantong plastik, atau karton. 


\section{HASIL DAN PEMBAHASAN}

\section{Kadar Air}

Kadar air sangat berpengaruh terhadap kualitas suatu bahan. Semakin rendah kadar air dalam rumput laut maka semakin baik kualitas rumput laut tersebut (Hidayat, 2004). Kadar air rumput laut kering yang dikeringkan dengan sinar matahari dan cabinet dryer dengan lama pengeringan berbeda (Gambar 1).

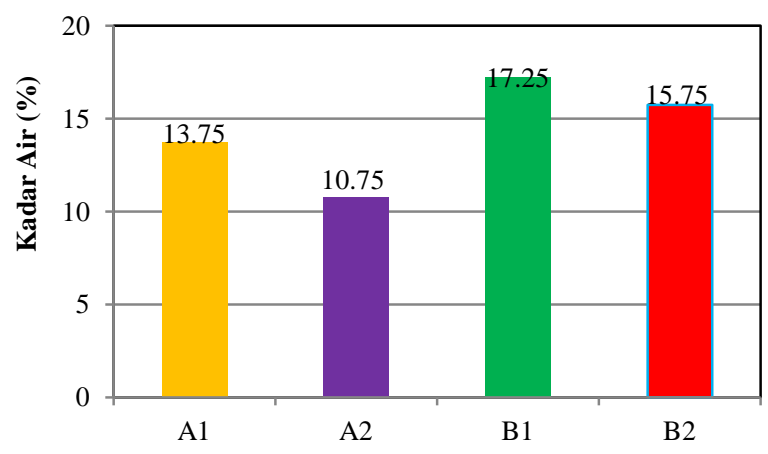

Gambar 1. Kadar air rumput laut kering dari rumput laut jenis Kappaphycus alvarezii yang dikeringkan dengan menggunakan 2 metode pengeringan.

Keterangan:

A1 : Pengeringan di bawah sinar matahari selama 24 jam (08.00-12.00)

A2 : Pengeringan di bawah sinar matahari selama 40 jam (12.00-16.00)

B1 : Pengeringan dengan cabinet dryer selama 12 jam

B2 : Pengeringan dengan cabinet dryer selama 24 jam

Rentang kadar air rumput kering dapat dilihat pada Gambar 1, yaitu berkisar antara 13,75-17,25\%. Berdasarkan histogram di atas menunjukkan bahwa ada perbedaan kadar air di setiap metode pengeringan yang dengan menggunakan sinar matahari dan cabinet dryer, nilai rata-rata untuk kadar air dari rumput laut merah kering dengan perlakuan A1 pengeringan di bawah sinar matahari selama 24 jam pada pukul 08.00-12.00 yaitu 13,75\%, dan pengeringan A2 sinar matahari selama 40 jam pada pukul 12.00-16.00 yaitu $10,75 \%$. Sedangkan pada perlakuan B1 pengeringan menggunakan cabinet dryer selama 12 jam yaitu $17,25 \%$ dan B2 pengeringan selama 24 jam yaitu $15,75 \%$ dengan suhu $60^{\circ} \mathrm{C}$.

Kadar air rumput laut kering pada penelitian ini terdapat pada perlakuan A1 Pengeringan di bawah sinar matahari selama 24 jam (08.00-12.00) memenuhi standar mutu rumput laut kering yang ditetapkan oleh SNI yaitu $26,77 \%$, bila dibandingkan dengan penelitian yang dilkukan oleh Harun $d k k$,
(2013) kadar air karaginan yang diperoleh yaitu $17,76 \%$.

Semakin rendah kadar air dalam rumput laut maka semakin baik kualitas rumput laut tersebut (Hidayat, 2004). selain itu pengeringan menggunakan cabinet dryer masih perlu pengeringan yang cukup lama untuk mendapatkan kadar air yang maksimum ditentukan. Bila dibanding dengan pengeringan di bawah sinar matahari masih memerlukan waktu yang cukup lama dan proses pengeringan yang tidak merata dan perubahan temperatur secara fluktuatif tersebut mempengaruhi kandungan air.

\section{Karbohidrat}

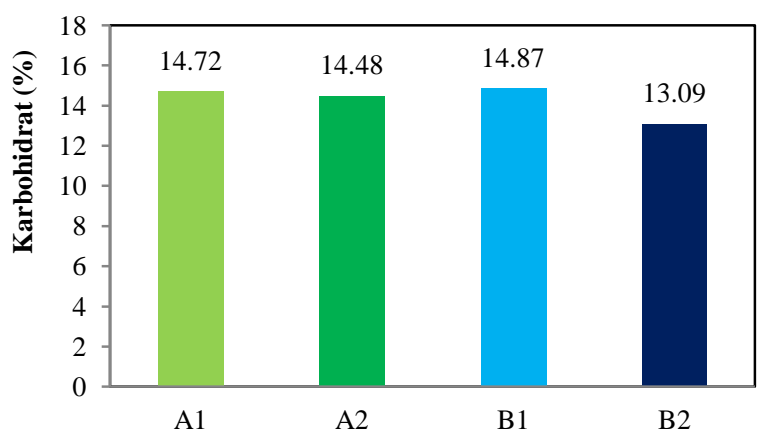

Gambar 2. Grafik hasil analisa karbohidrat pada rumput kering jenis Kappaphycus alvarezii.

Keterangan:

A1 : Pengeringan di bawah sinar matahari selama 24 jam (08.00-12.00)

A2 : Pengeringan di bawah sinar matahari selama 40 jam (12.00-16.00)

B1 : Pengeringan dengan cabinet dryer selama 12 jam

B2 : Pengeringan dengan cabinet dryer selama 24 jam

Winarno (1990) menyebutkan komponen utama dari rumput laut yang dapat digunakan sebagai bahan pangan adalah karbohidrat. akan tetapi karena kandungan karbohidrat sebagian besar terdiri dari senyawa gumi, maka hanya sebagian kecil saja dari kandungan karbohidrat tersebut yang dapat diserap dalam pencernaan manusia. Kadar karbohidrat yang terdapat pada rumput laut kering yang menggunakan metode pengeringan yang berbeda sinar matahari dan cabinet dryer dapat dilihat pada Gambar 2 di bawah ini yaitu berkisar antara 14,72-13,09\%. Kadar karbohidrat terendah terdapat pada perlakuan B2 yang dikeringkan dengan cabinet dryer selama 12 jam yaitu sebesar 13,09\%. Sedangkan nilai karbohidrat tertinggi terdapat pada perlakuan B1 yang dikeringkan dengan 
cabinet dryer selama 24 jam yaitu sebesar $14,87 \%$. Pada perlakuan A1 yang dikeringkan pada sinar matahari selama 24 jam (08.00 $12.00)$ yaitu $14,72 \%$, sedangkan pada perlakuan A2 yang dikeringkan pada sinar matahari selama 40 jam (12.00-16.00) yaitu $14,48 \%$.

Dari hasil yang diperoleh dari penelitian ini maka dapat diketahui bahwa proses pengeringan rumput laut merah kering dengan menggunakan metode yang berbeda tidak memenuhi standar yang ditentukan oleh SNI. Dari setiap perlakuan pengeringan yang diberikan serta temperatur yang digunakan masih belum dapat meningkatkan kadar karbohidrat. Mencermati kandungan karbohidrat yang terkandung di dalam karaginan dari rumput laut merah yang diteliti relatif rendah, maka untuk memperoleh kualitas karaginan yang berkualitas hendaknya kondisi lingkungan yang mendukung pertumbuhan rumput laut serta umur panen rumput laut diperhatikan dengan baik. Rumput laut yang digunakan dalam penelitian ini umur panennya sekitar 2 bulan. SNI 01-2891-1992 mensyaratkan bahwa secara kimiawi standar kadar karbohidrat pada rumput laut kering yaitu $35,57 \%$, maka kualitas rumput laut yang dikeringkan dengan metode yang berbeda tidak memenuhi standar yang ditentukan.

\section{Serat Kasar}

Serat yang terdapat dalam bahan pangan yang tidak tercerna mempunyai sifat positif bagi gizi dan metabolisme. Dietary fiber atau serat makanan merupakan komponen dari jaringan tanaman yang tahan terhadap proses hidrolisis oleh enzim dalam lambung dan usus (Winarno, 2002). Analisa serat kasar dimaksudkan untuk mengetahui jumlah serat kasar yang terkandung dalam rumput laut kering. Hasil analisa kadar serat dengan menggunakan metode SNI 01-2891-1992 dapat dilihat pada Gambar 3 di bawah ini berkisar antar 6,51-3,75\%. Kadar serat tertinggi A1 sinar matahari dengan lama pengeringan 24 jam (08.00-12.00) yaitu $6,51 \%$ sedangkan pada perlakuan A2 sinar matahari dengan lama pengeringan 40 jam (12.00-16.00) yaitu 3,08\%. Selanjutnya analisa kadar serat pada sampel B1 yang dikeringkan dalam cabinet dryer selama 12 jam sebesar $3,85 \%$, sedangkan pada sampel B2 yang dikeringkan dalam cabinet dryer selama 24 jam menurun hingga 3,75\%.

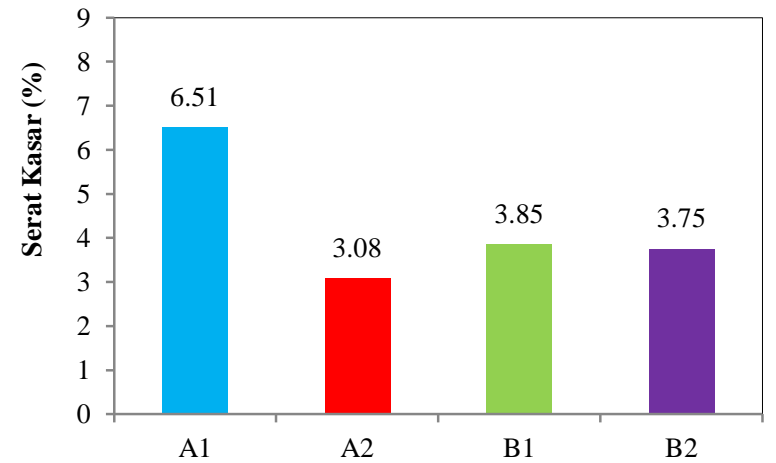

Gambar 3. Histogram serat kasar rumput laut kering jenis Kappaphycus alvarezii dengan proses pengeringan yang berbeda.

Keterangan:

A1 : Pengeringan di bawah sinar matahari selama 24 jam (08.00-12.00)

A2 : Pengeringan di bawah sinar matahari selama 40 jam (12.00-16.00)

B1 : Pengeringan dengan cabinet dryer selama 12 jam

B2 : Pengeringan dengan cabinet dryer selama 24 jam

Menurut Kasim (2004) bahwa kadar serat makanan dari rumput laut Kappaphycus alvarezii mencapai $67,5 \%$ yang terdiri dari $39,47 \%$ serat makanan yang tak larut air dan $26,03 \%$ serat makanan yang larut air. Rumput laut kering ini sebagai bahan baku produk karaginan yang berpotensi untuk dijadikan sebagai bahan makanan yang menyehatkan. Meskipun kadar serat dalam penelitian belum sesuai dengan yang disyaratkan SNI yaitu sebesar $0,95 \%$ namun dilakukan kadar serat makanan untuk melihat kontribusi penggunaan rumput laut. Sudarmadji $d k k$. (1989), mengatakan bahwa serat sangat penting dalam penilaian kualitas suatu makanan karena merupakan indeks untuk menentukan nilai gizi bahan dan efisiensi suatu proses pengolahan. Menurut (Suryaningrum, 1991) bahwa pemanenan rumput laut pada umur yang berbeda mempengaruhi nilai serat kasar. Rumput laut yang digunakan dalam penelitian tersebut umur panennya 35 hari sehingga serat kasar yang diperoleh sangat tinggi. Maka dari hasil penelitian ini serat kasar dari rumput laut kering masih di atas standar yang ditentukan SNI.

\section{Kadar Lemak}

Data analisis laboratorium kadar lemak rumput laut kering selama proses pengeringan berbeda dapat dilihat pada Gambar 4 di bawah ini. 


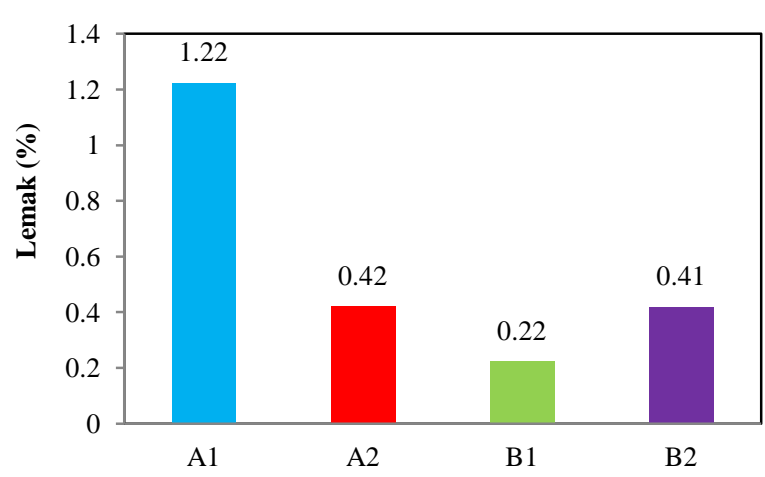

Gambar 4. Histogram penurunan kadar lemak rumput laut merah jenis Kappaphycus alvarezii selama proses Keterangan: pengeringan yang berbeda.

A1 : Pengeringan di bawah sinar matahari selama 24 jam (08.00-12.00)

A2 : Pengeringan di bawah sinar matahari selama 40 jam (12.00-16.00)

B1 : Pengeringan dengan cabinet dryer selama 12 jam

B2 : Pengeringan dengan cabinet dryer selama 24 jam

Hasil analisa kadar lemak rumput laut kering dapat dilihat pada Gambar 4 menunjukkan bahwa kadar lemak dari rumput laut merah yang telah dikeringkan dengan metode yang berbeda mendapat hasil setelah ekstraksi yaitu (A1) yang dikeringkan dengan sinar matahari selama 24 jam (08.00-12.00) sebesar 1,22\%, dan (A2) yang dikeringkan dengan sinar matahari selama 40 jam (12.0016.00) yaitu $0,42 \%$, kadar lemak (B1) yang dikeringkan dengan cabinet dryer selama 12 jam yaitu $0,22 \%$ dan (B2) yang dikeringkan dengan cabinet dryer selama 24 jam yaitu $0,41 \%$. Maka dari hasil penelitian ini kadar lemak rumput laut kering memenuhi standar SNI yang ditentukan. SNI 01-2891-1992 mensyaratkan kadar lemak rumput laut kering yaitu $0,51 \%$.

Tujuan analisa kadar lemak adalah untuk mengetahui kemungkinan daya simpan produk, karena lemak berpengaruh pada perubahan mutu selama penyimpanan bahan pangan (Winarno, 1997). Winarno (1997) menambahkan bahwa kerusakan lemak yang utama adalah timbulnya bau dan rasa tengik yang disebut dengan proses ketengikan. Hal ini disebabkan oleh oto-oksidasi asam lemak tidak jenuh yang dimulai dengan pembentukan radikal-radikal bebas karena faktor-faktor yang mempercepat reaksi seperti cahaya, panas, peroksida lemak atau hidroperoksida, logam berat dan logam porfirin.

\section{Rendemen Rumput Laut Merah (Kappaphycus alvarezii) Semi-Refined Carrageenan (SRC).}

Rendemen karaginan merupakan berat karaginan yang terkandung dalam rumput laut kering dan dinyatakan dalam persen. Semakin tinggi nilai rendemen semakin besar output yang dihasilkan. Pada penelitian ini, rendemen SRC Kappaphycus alvarezii dapat dilihat pada Gambar 5. Pada perlakuan B1 yang dikeringkan dengan cabinet dryer selama 12 jam pada temperatur $60^{\circ} \mathrm{C}$ adalah $56 \%$, sedangkan pada perlakuan B2 yang dikeringkan dengan cabinet dryer selama 24 jam pada temperatur $60^{\circ} \mathrm{C}$ adalah $42,6 \%$. Maka dari hasil penelitian ini menunjukkan bahwa rendemen SRC dari Kappaphycus alvarezii yang dikeringkan dengan cabinet dryer masih di atas standar yang ditentukan SNI yaitu 25\%. Jika dibandingkan dengan penelitian yang dilakukan oleh (Mtolera et al, 2004 dalam Distantina dkk, 2009) rendemen rumput laut yang dikeringkan di bawah sinar matahari berkisar antara 16-30\% jauh lebih rendah dibandingkan dengan pengeringan dengan cabinet dryer. SNI 012690-1998 mensyaratkan rendemen karaginan rumput laut kering tidak kurang dari $25 \%$.

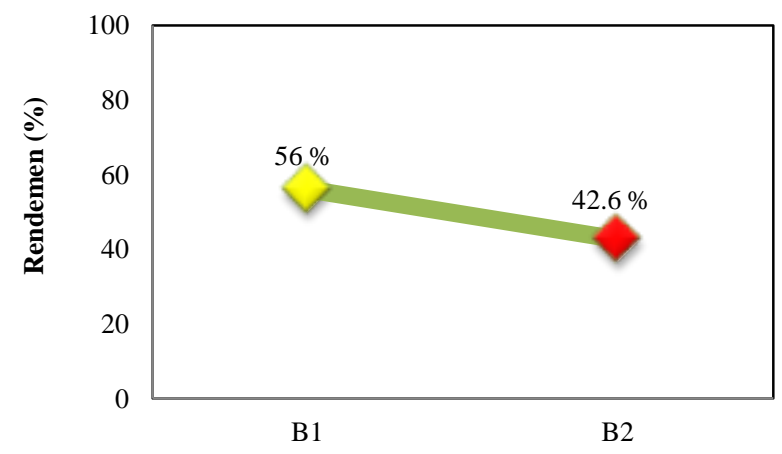

Gambar 5. Penurunan rendemen rumput laut merah (Kappaphycus alvarezii) yang dikeringkan dengan cabinet dryer.

Keterangan:

Pengeringan dengan cabinet dryer selama 12 jam

Pengeringan dengan cabinet dryer selama 24 jam

\section{KESIMPULAN DAN SARAN}

\section{Kesimpulan}

Dari hasil penelitian yang dilakukan dapat ditarik kesimpulan sebagai berikut:

1. Rendemen semi-refined carrageenan (SRC) dari rumput laut merah jenis Kappaphycus alvarezii yang dikeringkan dengan cabinet dryer adalah 56\%. Rendemen SRC ini di atas standar yang ditetapkan, SNI 01-2690- 
1998 mensyaratkan karaginan rumput laut kering tidak kurang dari $25 \%$.

2. Berdasarkan dua metode pengeringan yang dilakukan pada rumput laut merah jenis Kappaphycus alvarezii menunjukkan bahwa kualitas rumput laut kering memenuhi syarat mutu. Beberapa parameter pada penelitian ini menunjukkan bahwa kualitas karaginan dengan cabinet dryer memenuhi syarat mutu. Kadar lemak terendah terdapat pada pengeringan B1 selama 12 jam yaitu $0,22 \%$, sedangkan pada pengeringan di bawah sinar matahari menghasilkan kadar air terdapat pada pengeringan A1 di bawah sinar matahari yaitu $13,75 \%$.

3. Metode pengeringan dengan sinar matahari dan menggunakan cabinet dryer pada penelitian ini, menunjukkan hasil yang tidak memenuhi standar yaitu pada uji karbohidrat dan serat kasar. Hal ini disebabkan pengaruh rumput laut yang umur panennya sudah sekitar 2 bulan.

\section{Saran}

Berdasarkan hasil parameter yang diukur dalam penelitian ini, maka kualitas rumput laut merah (Kappaphycus alvarezii) yang dikeringkan pada cabinet dryer perlu waktu pengeringan yang lebih lama untuk mendapatkan hasil yang lebih baik.

\section{DAFTAR PUSTAKA}

Astawan M, Koswara S dan Herdiani F. 2004. Pemanfaatan Rumput Laut (Eucheuma cottonii) Untuk Meningkatkan Kadar Iodium dan Serat Pangan pada
Selai Dan Dodol. Jurnal Teknologi Dan Industri Pangan. Volume 15 (2): 61-69.

Badan Standar Nasional (BSN), 1992. SNI 01-2891-1992. Cara uji makanan dan minuman. Standar Nasional Indonesia.

Badan Standar Nasional (BSN), 1998. SNI 01-449-1998. Penetapan Kadar Rumput Laut Kering. Standar Nasional Indonesia.

Bintang Ye, Pongoh J dan Onibala H, 2013. Konstruksi Dan Kapasitas Alat Pengering Ikan Tenaga Surya Sistem Bongkar-Pasang. Fakultas Perikanan dan Ilmu Kelautan, Universitas Sam Ratulangi, Manado, Sulawesi Utara

Distantina, S., Fadilah, YC. Danarto, Wiratni, dan Moh. Fahrurrozi. 2009. Pengaruh Kondisi Proses Pada Pengolahan Eucheuma Cottonii Terhadap Rendemen dan Sifat Gel Karaginan. Universitas Sebelas Maret Surakarta dan Universitas Gadjah Mada Yogyakarta. Ekuilibrium.Vol. 8. No. 1. Januari 2009: $35-40$.

Hidayat, A., 2004. Pengaruh Kelembaban Udara Terhadap Kualitas Rumput Laut Kering Asin Jenis Eucheuma cottonii dan Gracillaria sp Selama Penyimpanan. Departemen Teknologi Hasil Perikanan, Fakultas Perikanan dan Ilmu Kelautan, Institut Pertanian Bogor, Bogor.

Kasim, S. R. 2004. Pengaruh Perbedaan Konsentrasi Dan Lamanya Waktu Pemberian Rumput Laut E. Cottoni Terhadap Kadar Lipid Serum Darah Tikus. Universitas Brawijaya. Malang. (Skripsi Fakultas Perikanan)

Sudarmadji, Slamet, Suhardi dan Bambang Haryono. 1989. Prosedur Analisa Untuk Bahan Makanan dan Pertanian. Liberty. Yogyakarta.

Suryaningrum T.D., Soekarto S.T., Manulang M. 1991. Identifikasi dan sifat fisika kimia karaginan. Kajian Mutu Komoditas Rumput Laut Budidaya Jenis Eucheuma cottonii dan Eucheuma spinosum. Jurnal Penelitian Pascapanen Perikanan. No 69

Winarno F.G., 1997. Kimia Pangan dan Gizi. Jakarta: PT Gramedia Pustaka Utama. 